PNL- 4590

NUREG/CR-2957 PNL-4590

\title{
Measurements of Gamma-Ray Dose from a Moderated 252Cf Source
}

Prepared by J. C. McDonald, R. V. Griffith, P. Plato, J. Miklos

Pacific Northwest Laboratory

Operated by

Battelle Memorial Institute

Prepared for

U.S. Nuclear Regulatory

Commission 


\section{NOTICE}

This report was prepared as an account of work sponsored by an agency of the United States Government. Neither the United States Government nor any agency thereof, or any of their employees, makes any warranty, expressed or implied, or assumes any legal liability of responsibility for any third party's use, or the results of such use, of any information, apparatus, product or process disclosed in this report, or represents that its use by such third party would not infringe privately owned rights.

\section{Availability of Reference Materials Cited in NRC Publications}

Most documents cited in NAC publications will be available from one of the following sources:

1. The NRC Public Document Room, 1717 H Street, N.W. Washington, DC 20555

2. The NRC/GPO Sales Program, U.S. Nuclear Regulatory Commission, Washington, DC 20555

3. The National Technical Information Service, Springfield, VA 22161

Although the listing that follows represents the majority of documents cited in NRC publications, it is not intended to be exhaustive.

Referenced documents available for inspection and copying for a fee from the NAC Public Document Room include NRC correspondence and iriternal NRC memoranda; NRC Office of Inspection and Enforcement bulletins, circulars, information notices, inspection and investigation notices; Licensee Event Reports; vendor reports and correspondence; Commission papers; and applicant and licensee documents and correspondence.

The following documents in the NUREG series are available for purchase from the NAC/GPO Sales Program: formal NAC staff and contractor reports, NAC-sponsored conference proceedings, and NAC booklets and brochures. Also available are Regulatory Guides, NRC regulations in the Code of Federal Regulations, and Nuclear Regulatory Commission /ssuances.

Documents available from the National Technical Information Service include NUREG series reports and technical reports prepared by other federal agencies and reports prepared by the Atomic Energy Commission, forerunner agency to the Nuclear Regulatory Commission.

Documents available from public and special technical libraries include all open literature items, such as books, journal and periodical articles, and transactions. Federal Register notices, federal and state legislation, and congressional reports can usually be obtained from these libraries.

Documents such as theses, dissertations, foreign reports and transiations, and non-NRC conference proceedings are available for purchase from the organization sponsoring the publication cited.

Single copies of NRC draft reports are available free upon written request to the Division of Technical Information and Document Control, U.S. Nuclear Regulatory Commission, Washington, DC 20555.

Copies of industry codes and standards used in a substantive manner in the NRC regulatory process are maintained at the NRC Library, 7920 Norfolk Avenue, Bethesda, Maryland, and are available there for reference use by the public. Codes and standards are usually copyrighted and may be purchased from the originating organization or, if they are American National Standards, from the American National Standards Institute, 1430 Broadway, New York, NY 10018. 
NUREG/CR-2957

PNL-4590

$\mathrm{RH}$

\section{Measurements of Gamma-Ray Dose from a Moderated 252Cf Source}

Manuscript Completed: April 1983

Date Published: June 1983

Prepered by

J. C. McDonald, R. V. Griffith*, P. Plato*", J. Miklos**

Pacific Northwest Laboratory

Richland, WA 99352

"Lawrence Livermore National Laboratory

** University of Michigan

\section{Prepared for}

Division of Facility Operations

Office of Nuclear Regulatory Research

U.S. Nuclear Regulatory Commission

Washington, D.C. 20555

NRC FIN B2460 



\section{ABSTRACT}

The ganma-ray dose fraction from a moderated ${ }^{252} \mathrm{Cf}$ source was determined by using three types of dosimetry systems. Measurements were carried out in air at a distance of $35 \mathrm{~cm}$ from the surface of the moderating sphere $(50 \mathrm{~cm}$ from the source which is at the center of the sphere) to the geometrical center of each detector. The moderating sphere is $0.8 \mathrm{~mm}$ thick stainless steel shell filled with $\mathrm{D}_{2} 0$ and covered with $0.5 \mathrm{~mm}$ of cadmium. Measurements were also carried out with instruments and dosimeters positioned at the surface of a $40 \mathrm{~cm} \mathrm{x}$ $40 \mathrm{~cm} \times 15 \mathrm{~cm}$ plexiglass irradiation phantom whose front surface was also $35 \mathrm{~cm}$ from the surface of the moderating sphere. A-150 tissue-equivalent (TE) plastic ionization chambers and a TE proportional counter (TEPC) were used to measure tissue dose, from which the neutron dose equivalent was computed. The ratio of gamma-ray dose to the neutron dose equivalent was determined by using a relatively neutron insensitive Geiger-Mueller (GM) counter and thermoluminescent dosimeters (TLD). In addition, the event-size spectrum measured by the TEPC was also used to compute the gamma-ray dose fraction. The average value for the ratio of gamma-ray dose to neutron dose equivalent was found to be 0.18 with an uncertainty of about $\pm 18 \%$. 

CONTENTS

ABSTRACT

iii

ACKNOWLEDGMENTS .

INTRODUCTION

DESCRIPTION OF EXPERIMENTAL PROCEDURES

MATERIALS AND METHODS.

CALCULATIONS OF DOSE AND DOSE EQUIVALENT

DOSE EQUIVALENT CONVERSION FACTORS

CORRECTIONS AND APPROXIMATIONS .

UNCERTAINTIES

RESULTS

REFERENCES .

v 
FIGURE

1 Event-Size Distribution from Moderated ${ }^{252} \mathrm{Cf}$.

7

TABLES

1 Radiation Properties of ${ }^{252} \mathrm{Cf}$.

2 Results

vi 


\section{ACKNOWLEDGMENTS}

The authors wish to acknowledge the enthusiastic support of Ms. Nancy A. Dennis of the Nuclear Regulatory Commission. We also appreciate the helpful suggestions of Drs. M. Ehrlich, C. Eisenhauer and R. Schwartz of the National Bureau of Standards. 

MEASUREMENTS OF GAMMA-RAY DOSE

FROM A MODERATED 252 CF SOURCE

\section{INTRODUCTION}

The Nuclear Regulatory Commission (NRC) has initiated a testing program for personnel dosimetry processors, and part of this program includes the evaluation of neutron dosimeters. The source of neutrons used for the performance testing program now underway at the University of Michigan (UM) was designed by Schwartz and Eisenhauer (1980) of the National Bureau of Standards (NBS). Earlier work (Griffith 1978) with moderated source of neutrons has also been carried out by Griffith and co-workers at the Lawrence Livermore National Laboratory (LLNL).

The NBS-developed source was designed to provide a neutron spectrum which would simulate the type of spectra encountered in the vicinity of a reactor. In order to do this, a $252 \mathrm{Cf}$ source was surrounded by a $30-\mathrm{cm}$ diameter stainless steel shell $0.8 \mathrm{~mm}$ thick filled with $\mathrm{D}_{2} \mathrm{D}$. The sphere was also covered with an outer layer of cadmium, $0.5 \mathrm{~mm}$ thick. The use of cadmium avoids the calculational difficulties posed by thermal neutrons, which do not contribute significantly to the dose equivalent. The source was fabricated at the 0ak Ridge National Laboratory.

Initial results of the first two rounds of testing of the performance of personnel dosimetry processors have been reported (Plato 1980). The neutron source used for the second round of testing was unmoderated 252 Cf. Results of the third round of testing, recently completed at the University of Michigan, are reported in NUREG/CR-2891 by Plato and Miklos (1982). For the third round of testing, the neutron source was changed to the moderated $252 \mathrm{Cf}$ source described above. Prior to the third round of testing, dosimetry processors were given a copy of the Criteria for Testing Personnel Dosimetry Performance, Draft Standard of the Health Physics Society Standards Committee which, in the Appendix, gave processors the ratio of gamma-ray to neutron dose equivalent of approximately 0.3 . During the test, several processors reported to the University of Michigan that this ratio appears to be closer to 0.2 .

It was decided that several indegendent measurements of the gamma-ray dose equivalent rate from the moderated ${ }^{252} \mathrm{Cf}$ source should be obtained using several measurement techniques. Therefore, a joint effort by the Pacific Northwest Laboratory (PNL), LLNL and UM was proposed and executed. This report describes and summarizes these measurements and compares them to previous estimates of the gamma-ray dose equivalent. 


\section{DESCRIPTION OF EXPERIMENTAL PROCEOURES}

MATERIAL AND METHODS

The $\mathrm{D}_{2} \mathrm{O}$-moderated californium-252 source used at UM is an NBS source (NS-109). This source was used for Test \#3 of the NRC pilot study of dosimetry processor performance testing. The neutron emission rate was measured at NBS prior to Test \#3. Neutron dose equivalent rate from this source is determined using the NBS-measured neutron emission rate and the conversion factor $9.3 \times$ $10^{-9}$ rem $\mathrm{cm}^{2}$ given in the ANSI N13.11 1982 standard. The neutron dose equivalent rate on June 9, 1982 was calculated using the following equation:

$$
\begin{gathered}
\dot{H}_{n}=\frac{\left(5.5849 \times 10^{9} \mathrm{n} / \mathrm{s}\right)\left(9.3 \times 10^{-9} \mathrm{rem} \cdot \mathrm{cm}^{2}\right)(60 \mathrm{~s} / \mathrm{min})(1000 \mathrm{mrem} / \mathrm{rem})}{4 \pi(50 \mathrm{~cm})^{2}} \\
\dot{H}_{n}=99.20 \mathrm{mrem} / \mathrm{min} 050 \mathrm{~cm}
\end{gathered}
$$

The neutron dose equivalent rate at $50 \mathrm{~cm}$ from the source on June 10, 1982 was calcualted to be $99.13 \mathrm{mrem} / \mathrm{min}$.

The $\mathrm{O}_{2} \mathrm{O}$-moderated californium-252 source is housed at the UM Willow Run Laboratory. In its irradiation position, the source is approximately $250 \mathrm{~cm}$ above the concrete floor, approximately $205 \mathrm{~cm}$ from the wooden ceiling, and $400 \mathrm{~cm}$ from the nearest concrete block wall. The source is stored in a water filled pit approximately $120 \mathrm{~cm}$ in diameter and $120 \mathrm{~cm}$ in depth, directly below the moderated sphere.

Table 1 shows some of the radiation properties of the $252 \mathrm{Cf}$ source (ICRU 1977). Average neutron and gamma-ray energy will be lowered by the presence of the moderating medium.

$$
\text { TABLE 1. Radiation Properties of }{ }^{252} \mathrm{Cf}
$$

Half-liffe:

Decay Modes:

\subsection{5 years}

96.9\% a-decay

3.1\% Spontaneous fission

(average 3.8 neutrons per fission)

Unmoderated

Mean Neutron Energy:

$2.1-2.3 \mathrm{MeV}$

Specific Neutron Emission Rate:

$2.31 \times 10^{6} \mathrm{n} \cdot \mathrm{s}^{-1} \cdot \mu \mathrm{g}^{-1}$

$\underline{D_{2} 0+C d+S t a i n l e s s ~ S t e e l ~ M o d e r a t e d ~}$

Mean Neutron Energy:

$0.5 \mathrm{MeV}$

Specific Neutron Emission Rate*: $2.06 \times 10^{6} n \cdot s^{-1} \cdot \mu g^{-1}$

* This number is 0.89 times the unmoderated rate, since about $11 \%$ of the neutrons are below the Cd cutoff (Schwartz 1980). 
The instruments chosen for these measurements have been used for similar work which has been reported previously (Griffith 1978). LLNL provided spherical ionization chambers constructed of A-150 plastic (ICRU 1977) which were manufactured by Far West Technology Inc. (FWT), Goleta, CA. These chambers were used to measure the total tissue dose (neutrons plus gamma-rays). One chamber used was a Model IC- 80 with a volume of approximately $80 \mathrm{me}$. The inner diameter of this chamber is $5.66 \mathrm{~cm}$ and the wall thickness is 0.229 . In addition, a FWT Model IC-17 spherical chamber was also used. Its inner diameter is $1.27 \mathrm{~cm}$, its wall thickness is $0.51 \mathrm{~cm}$, and its volume is approximately $1 \mathrm{ml}$. These chambers were operated using a potential of $300 \mathrm{~V}$ and readings were taken with both polarities. Methane-based tissue-equivalent (TE) gas (ICRU 1977) flowed through the chambers at a rate of approximately $10 \mathrm{me} / \mathrm{min}$, and, since the chambers were vented to air, appropriate corrections were made for local temprature and atmospheric pressure. Calibrations of these chambers at LLNL agreed to within $2 \%$ of the manufacturer's calibration. The LLNL calibration was used for these measurements.

A Geiger-Mueller detector (FWT Model GM-2) from LLNL was also used to measure gamma-ray tissue dose. Since this detector is somewhat sensitive to thermal neutrons (Wagner 1961), data was taken with and without a $6 \mathrm{Li}$ shield surrounding the counter tube. It was found that the difference between these conditions was not significant for this source. The response of the G-M detector to fast neutrons from the $252 \mathrm{Cf}$ source was estimated to be less than $1 \%$ (Klein 1979), therefore this correction factor was assumed to be negligible.

TLDs from LLNL were exposed at the same position as the other detectors. These dosimeters consisted of three 7 Li-enriched LiF TLD chips mounted in plastic discs approximately $4 \mathrm{~cm}$ in diameter and about $0.4 \mathrm{~cm}$ in thickness. These dosimeters are of the standard TLD types worn by workers at LLNL and are normally attached to a security document. Calibrations of each dosimeter were carried out using ${ }^{137} \mathrm{Cs}$ and $60 \mathrm{Co}$ sources, and corrections for the fast neutron response of this type of dosimeters were taken from the work of Wingate (1967).

The Pacific Northwest Laboratory (PNL) provided a FWT spherical proportional counter (Model LET 1/2). This counter has an inner diameter of $1.27 \mathrm{~cm}$ with a $0.25 \mathrm{~cm}$ thick wall, and was filled to a pressure of 68 Torr with propanebased TE gas (ICRU 1977). This pressure corresponds to an equivalent diameter of approximately $2 \mu \mathrm{m}$ in unit-density tissue, due to the reduction in pressure. This counter provided a simultaneous measurement of both neutron and gamma-ray tissue dose which could be separated in a manner to be described later (Weaver 1977).

The spherical proportional counter was operated at two potentials, $+475 \mathrm{~V}$ for neutron portion and $+645 \mathrm{~V}$ for the gamma-ray portion. Pulses were amplified using an Ortec Model 142-PC preamplifier, followed by approximately $25 \mathrm{~m}$ of low-noise cable which was connected to a Canberra Model 1412 spectroscopy amplifier. Shaped pulses were then accumulated using a Canberra Series 40 multi-channel analyzer. 
Calibration of the counter was carried out in two ways. The built-in ${ }^{241}$ Am alpha particle source produces a distribution of pulses with an energy - deposition estimated to be $88 \mathrm{keV} / \mu \mathrm{m} \pm 3 \%$ (McDonald 1979). In addition, the position of the "proton-edge," which occurs because of the maximum in the proton stopping power versus energy relationship (Barkas 1964), was estimated to occur at approximately $105 \mathrm{keV} / \mu \mathrm{m}$ (Glass 1972). These two reference points were used to establish the energy deposition scale.

The output of an electronic pulser was set to coincide with the alpha source peak. The main amplifier gain was then increased, in order to acquire the gamma-ray portion of the spectrum, and the pulser peak was then noted to obtain the calibration of this portion of the spectrum.

The energy deposition scale is expressed in terms of lineal energy, $y$. This quantity is the amount of energy deposited, by charged particles, divided by the mean chord length in the volume of interest. In the case of a sphere this is $2 / 3$ the diameter. A useful method for presenting the data is to form the product of the number of counts, or frequency, $f$, with the lineal energy, $y$, squared. When this product is plotted versus the lineal energy on a semilog scale, the area under the curve is proportional to dose. This property follows from the fact that the derivative of $\ln y$ is $1 / y$, so that:

$$
\int_{a}^{b} y^{2} \cdot f(y) d(\ln y)=\int_{a}^{b} y \cdot f(y) d y
$$

Since $y \cdot f(y)$ dy is equal to the energy imparted in the lineal energy range between $y$ and $y+d y$, the second integral is proportional to the dose deposited by particles with lineal energies between the limits a and $b$.

The data obtained in this experiment is shown in Figure 1, and this presentation clearly shows the separation of events due to gamma-rays and neutrons. This separation occurs because the secondary charged particles created by gammaray interactions (which are electrons) cannot deposit more than about $20 \mathrm{keV} / \mu \mathrm{m}$. The separation is quite clear in this case, since there is a "valley" in the curve at about $10 \mathrm{keV} / \mu \mathrm{m}$. The events above this point are predominately due to recoil protons created by neutrons interactions in the counter wall.

The hatched lines indicate the spread in the raw data, and the decrease in this spread, shown at about $4 \mathrm{keV} / \mu \mathrm{m}$, is due to a gain change in the pulse amplifier. The dashed lines indicate the smoothed curves that were passed through the data in order to delineate the areas of gamma-ray and neutron events. 


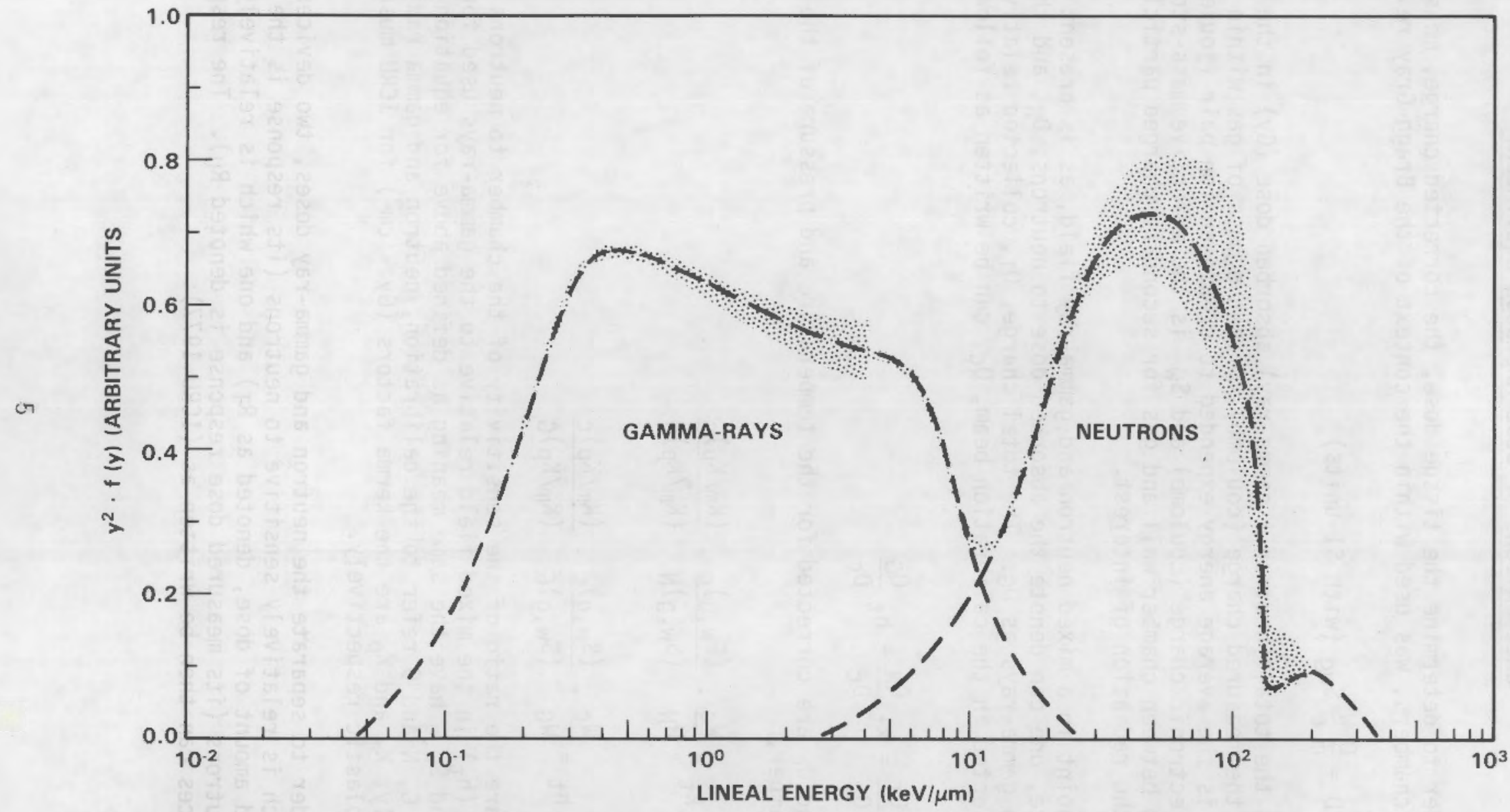

FIGURE 1. Event-Size Distribution from Moderated ${ }^{252} \mathrm{Cf}$ 


\section{CALCULATIONS OF DOSE AND DOSE EQUIVALENT}

In order to determine the tissue dose, the corrected charge, measured with the TE ion chambers, was used within the context of the Bragg-Gray relationship:

$$
D=\frac{Q}{m} \frac{W}{e} S_{w g} \text { (with SI units) }
$$

where, $D$ is the total (neutron + gamma-ray) absorbed dose (Gy) in the chamber wall, $Q$ is the measured charge (coulomb), $m$ is the mass of gas within the chamber $(g), W$ is the average energy expended to create an ion pair (joules/coulomb), $e$ is the electronic charge (coulomb) and $S_{w g}$ is the effective mass-stopping power ratio between chamber wall and gas for secondary charged particles generated by the radiation of interest.

At a point in a mixed neutron and gamma-ray field, as is present near a ${ }^{252} \mathrm{Cf}$ source, one can denote the absorbed dose to neutrons, $\mathrm{D}_{\mathrm{N}}$, and the absorbed dose due to gamma-rays as $D_{G}$. The total charge, QT, collected relative to the charge collected in the calibration beam, $Q_{c}$, can be written as follows (ICRU 1977):

$$
\frac{Q_{T}}{Q_{C}}=k_{t} \frac{Q_{N}}{D_{C}}+h_{t} \frac{Q_{G}}{D_{C}}
$$

where $Q_{T}$ and $Q_{C}$ are corrected for the temperature and pressure of the gas in the ion chamber,

$$
\text { and, } \quad \begin{aligned}
k_{t} & =\frac{W_{C}}{W_{N}} \cdot \frac{\left(S_{W, g}\right)_{c}}{\left(S_{W, g}\right)_{N}} \cdot \frac{\left(K_{m} / K_{p}\right)_{c}}{\left(K_{m} / K_{p}\right)_{N}} \\
h_{t} & =\frac{W_{C}}{W_{G}} \cdot \frac{\left(S_{W}, g\right)_{c}}{\left(S_{W}, g\right)_{G}} \cdot \frac{\left(K_{m} / K_{p}\right)_{C}}{\left(K_{m} / K_{p}\right)_{G}}
\end{aligned}
$$

$k_{t}$ and $h_{t}$ are the ratio of the sensitivity of the chamber to neutrons $\left(k_{t}\right)$ and gamma-rays $\left(h_{t}\right)$ in the mixed field relative to the gamma-rays used for calibration. $H$ and $S_{w, g}$ have the same meaning as defined above for equation 4 and the subscripts $C, N$ and $G$ refer to the calibration, neutron and gamma radiations, respectively, $\mathrm{K}_{\mathrm{m}}$ and $\mathrm{K}_{\mathrm{p}}$ are the kerma factors (Gy $\cdot \mathrm{cm}^{2}$ ) for ICRU muscle-tissue and $\mathrm{A}-150$ plastic respectively.

In order to separate the neutron and gamma-ray doses, two devices are used, one of which is relatively sensitive to neutrons (its response is the observed or measured amount of dose, denoted as $\mathrm{R}_{T}$ ) and one which is relatively insensitive to neutrons ( $i$ ts measured dose response is denoted $R_{U}$ ). The response of these devices can then be written as (ICRU 1977): 


$$
\begin{aligned}
& R_{T}=k_{T} D_{N}+h_{T} D_{G} \\
& R_{U}=k_{U} D_{N}+h_{U} D_{G}
\end{aligned}
$$

where $h_{u}$ and $k_{u}$ refer to the neutron insensitive device and correspond to the quantities $h_{t}$ and $k_{t}$ which were defined previously. Solving for $D_{N}$ and $D_{G}$, and making the assumption that $h_{T}=h_{u}=k_{T}=1$ yields the following solutions:

$$
\begin{aligned}
& D_{N}=\frac{R_{T}-R_{u}}{1-k_{u}} \\
& D_{G}=\frac{R_{u}-k_{u} R_{T}}{1-k_{u}}
\end{aligned}
$$

The assumption of setting $h_{T}=h_{u}=k T=1$ is justified since the response of both the neutron sensitive and insensitive devices is nearly the same to gammarays and $\mathrm{k}_{\mathrm{T}}$ is close to unity for these radiations. In equations 10 and 11 , $R_{T}$ and $R_{u}$ are measured and $k_{u}$ is set equal to zero for these instruments (KTein 1979).

In order to obtain tissue dose a correction was applied to account for the absorption of neutrons in the wall of each chamber. The numerical values for all factors used in this work are contained below in the Corrections and Approximations section.

The gamma-ray dose in tissue was computed from the G-M detector measurements with the following equation:

$$
D_{G}=\text { Counts } \cdot R_{G M} \cdot C_{D} \cdot C_{T}
$$

where $D_{G}$ is the gamma-ray dose, $R_{G M}$ (Roentgens/Count) is the resonse of the G-M detector to the calibration gamma-ray source, $C_{D}$ is the dead-time correction, and $\mathrm{C}_{\mathrm{T}}$ is the factor to convert from roentgen to tissue rads.

The neutron and gamma-ray dose ratios were determined using the TEPC data by computing the area under the respective portions of the distributions of $y^{2} \cdot f(y)$ versus $\log y$ shown in Figure 1 . The same type of corrections applied to the ionization chambers were applied to the TEPC. There dose(D) was determined from the TEPC data using the following formula:

$$
D=\text { Constant } \sum_{h_{1}}^{h_{2}} \frac{c \cdot h \cdot N(h)}{M e V} \cdot \rho \cdot V
$$

where $h$ is the MCA channel, $N(h)$ is the number of pulses in $h, h_{1}$ and $h 2$ are the limits of either the neutron or gamma-ray region, $c$ is the instrument calibration, $\rho$ is the density of the gas and $V$ is the chamber volume (ICRU 1977). 


\section{DOSE EQUIVALENT CONVERSION FACTORS}

The spectrum of gamma-rays emitted from the source was not measured, however an estimate of their mean effective energy was determined to be approximately $400 \mathrm{keV}$ by Plato and Miklos using the response of TLDs. Due to the rather large thickness of absorber $\left(15 \mathrm{~cm}\right.$ of $\mathrm{D}_{2} 0+0.08 \mathrm{~cm}$ stainless steel $+0.05 \mathrm{~cm} \mathrm{Cd}$ ) it is unlikely that there were large numbers of low energy ganmarays present at the measurement position. The detectors have a flat response above about 40-50 keV and it is assumed in this work that gamma-ray dose equivalent is identical to the gamma-ray dose.

Since the measurement was carried out using a unidirectional, indirectly ionization radiation having secondary charged particles of short range in tissue, the product of the tissue dose times an effective quality factor was used to compute dose equivalent (ICRU 1976). The neutron dose equivalent was computed from the product of tissue dose and the conversion factor from tissue dose to dose equivalent. For measurements on phantom in the moderated ${ }^{252} \mathrm{Cf}$ field a value of 10.2 for the quality factor was taken from the work of Ing and cross (1982). 
The following table contains the various correction factors applied to the dosimeters. The symbols have been defined previously (ICRU 1977).

$$
\begin{aligned}
& \frac{W_{N}}{W_{G}}=1.075(a) \\
& \frac{\left(S_{W g}\right)_{N}}{\left(S_{W g}\right)_{G}} \sim 1 \\
& \frac{K_{m}}{K_{p}}=1.021(a)
\end{aligned}
$$

The correction ( $F$ ) to standard temperature and pressure was computed using the measured temperature $(T)$ and pressure $(P)$ as follows:

$$
F=\frac{273.2+T}{295.2} \cdot \frac{P}{760}
$$

The wall attenuation for neutrons for the chambers was:

$$
\frac{1 \mathrm{ml} \text { chamber }}{17 \%} \quad \frac{80 \mathrm{ml} \text { chamber }}{7.5 \%}
$$

The conversion from exposure to tissue dose was taken as (ICRU 1977):

$$
0.0096 \mathrm{~Gy} / \mathrm{R}(0.96 \mathrm{rad} / \mathrm{R})
$$

\section{UNCERTAINTIES}

The uncertainties for the ionization chamber measurements are mainly due to uncertainties in: W-values, of approximately $3 \%$, the stopping power ratios of approximately $1.5 \%$, the kerma factors, of approximately $\pm 2 \%$ and in the chamber calibration $\pm 2.5 \%$. An additional uncertainty of about $\pm 5 \%$ is assigned to the separation of neutron and gamma-ray dose along with $\pm 5 \%$ experimental uncertainties. When compounded in quadrature, the overall uncertainty for the ionization chambers are estimated to be about $\pm 9 \%$.

The TEPC has errors contributed from counting statistics, approximately $\pm 5 \%$, lack of exact knowledge of the counter volume, approximately $\pm 3 \%$, uncertainty in the pressure and density of the gas, about $\pm 2 \%$ and about $\pm 3 \%$ in the calibration, and about $\pm 5 \%$ experimental uncertainties leading to an overal1

(a) Private communication, L. J. Goodman, National Bureau of Standards (1982). 
value of about $\pm 9 \%$. The G-M detector has about a $\pm 3 \%$ uncertainty due to its calibration approximately $\pm 2.5 \%$ due to its neutron sensitivity, $\pm 5 \%$ due to counting statistics and $\pm 5 \%$ experimental uncertainty leading to an overa 11 uncertainty of about $\pm 8 \%$. The TLDs have an uncertainty in their neutron sensitivity which contributes about $\pm 5 \%$, and the uncertainty in calibration contributes about $\pm 5-7 \%$ leading to an overall uncertainty of $\pm 9 \%$.

The conversion factors used to calculate dose equivalent from tissue dose represented a systematic error for both the chambers and the TEPC, and probabiy had an uncertainty of $\pm 15 \%$.

The overall uncertainties in the specifications of dose and dose equivalent are conservatively estimated to be as follows:

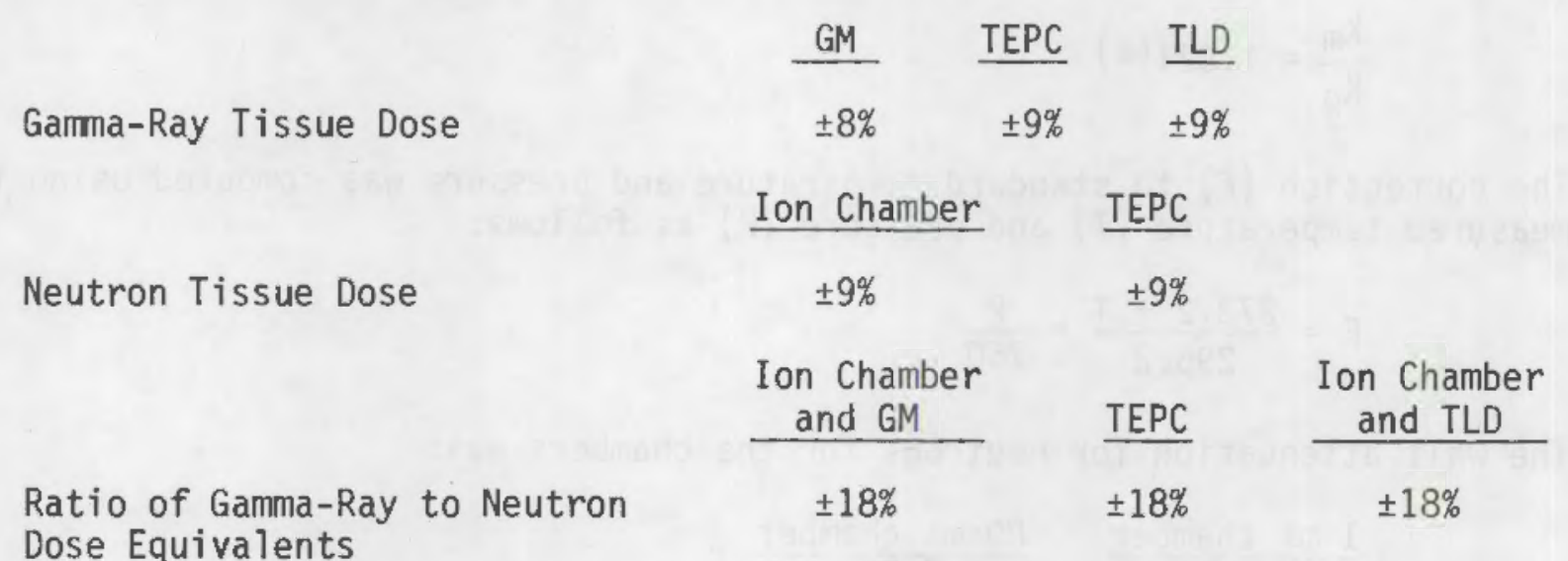




\section{RESULTS}

Table 2 lists the results of the measurements. All values are in terms of tissue dose rate (mrad/min) given at a distance of $50 \mathrm{~cm}$ from the center of the $\mathrm{D}_{2} 0$ filled moderator sphere to the geometrical center of each detector. The values indicated were determined from the LLNL ion chamber, TLD's and G-M along with the PNL TEPC system. Each value is the average of from two to four individual measurements.

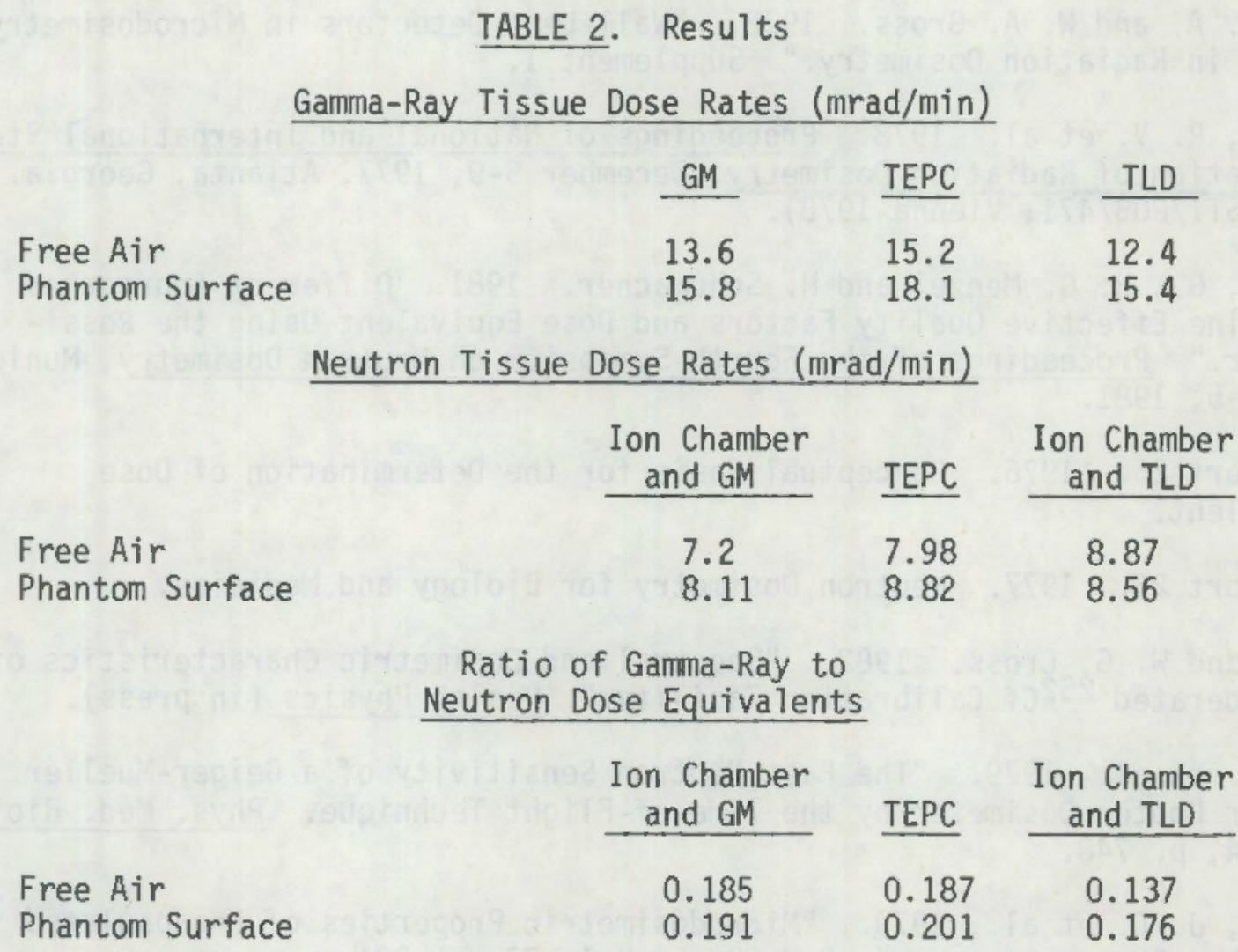

Plato and Miklos have measured the gamma-ray percentage for the University of Michigan ${ }^{252} \mathrm{Cf}$ source at the phantom surface using TLDs. The value they obtained was approximately 0.16 , which is in good agreement with the values obtained using the G-M and TEPC.

The values of the neutron tissue dose rate measurements were $10-15 \%$ lower than the rate computed from an NBS-based neutron emission determination used by the University of Michigan ( $82.7,90$ and 87.3 versus $99.2 \mathrm{mrem} / \mathrm{min}$ ). Although this is just within the expected uncertainties, it may indicate that the value of the quality factor used (10.2) should have had a larger uncertainty, or should have been somewhat larger itself.

The techniques used in this study yielded slightly different results, but the differences were within the expected uncertainties. The overall average value for the gamma-ray dose equivalent ratio at the surface of the irradiation phantom was computed by taking an arithmetic mean of the results indicated in Table 2, and this value was found to be 0.18 with an uncertainty of $\pm 18 \%$. 


\section{REFERENCES}

ANSI Draft Standard N13.11. 1981. American National Standards Institute, 1430 Broadway, New York, New York.

Barkas, W. H. and M. J. Berger. 1964. Tables of Energy Losses and Ranges of Heavy Charged Particles. NASA SP-3013.

GTass, W. A. and W. A. Gross. 1972. "Wall-Less Detectors in Microdosimetry in Topics in Radiation Dosimetry." Supplement 1.

Griffith, R. V. et al. 1978. Proceedings of National and International Standardization of Radiation Dosimetry, December 5-9, 1977, Atlanta, Georgia. IAEA, STI/PUB/471, Vienna 1978).

Hartmann, G., H. G. Menzel and H. Schumacher. 1981. Different Approaches Determine Effective Quality Factors and Dose Equivalent Using the RossiCounter." Proceedings of the Fourth Symposium on Neutron Dosimetry, Munich, June $1-5,1981$.

ICRU Report 25. 1976. Conceptual Basis for the Determination of Dose Equivalent.

ICRU Report 26. 1977. Neutron Dosimetry for Biology and Medicine.

Ing. H. and W. G. Cross. 1982. "Spectral and Dosimetric Characteristics of a $\mathrm{D}_{2}$ D-Moderated ${ }^{252} \mathrm{Cf}$ Calibration Facility." Health Physics (in press).

Klein, H. et al. 1979. "The Fast Neutron Sensitivity of a Geiger-Mueller Counter Photon Dosimeter by the Time-of-Flight Technique. Phys. Med. Biol. Vol. 24, p. 748.

McDonald, J. C. et al. 1979. "Microdosimetric Properties of Encapsulated ${ }^{125} \mathrm{I}$ and Other Photon Sources." Rad. Res., Vol. 77, p. 221.

Plato, P. and G. Hudson. 1980. "Performance Testing of Personnel Dosimetry Services: Supplementary Report on a Two-Year Pilot Study October 1977 through December 1979." NUREG/CR-130 Division of Technical Information and Document Control, U.S. Nuclear Regulatory Commission, Washington, D.C.

Plato. P. and J. Miklos. 1982. "Performance Testing of Personnel Dosimetry Testing Services: Final Report for Test \#3" NUREG/CR-2891 Division of Technical Information and Document Control, U.S. Nuclear Regulatory Commission, Washington, D.C.

Schwartz, R. B. and C. M. Eisenhauer. 1980. "The Design and Construction of $\mathrm{D}_{2} \mathrm{O}$-Moderated ${ }^{252} \mathrm{Cf}$ Source for Calibrating Neutron Personnel Dosimeters Used at Nuclear Power Reactors." NUREG/CR-1204, January 1980. 
Wagner, E. B. and G. S. Hurst. 1961. "A Geiger-Mueller $\gamma$-Ray Dosimeter with Low Neutron Sensitivity." Health Physics, Vol. 5, p. 20.

Weaver, K., H. Bichsel, J. Eenmaa and P. Wootton. 1977. "Measurement of Photon Dose Fraction in a Neutron Therapy Beam." Med. Phys. 4, p. 379.

Wingate, C. L., E. Tochilin and N. Goldstein. 1967. Response of Lithium Fluoride to Neutrons and Charged Particles. AEC Conference, Report No. 650637, pp. 421-434. 

No. of

Copies

\section{OFFSITE}

U.S. Nuclear Regulatory Commission

Division of Technical Information and Document Control

7920 Norfolk Avenue

Bethesda, MD 20014

4 R. E. Alexander

U.S. Nuclear Regulatory Commission

Office of Nuclear Regulatory Research

Washington, D.C. 20555

20 N. A. Dennis

U.S. Nuclear Regulatory Commission

Region I

631 Park Avenue

King of Prussia, PA 19406

M. Ehrlich

U.S. Department of Commerce National Bureau of Standards Washington, D.C. 20234
No. of

Copies

E. J. Vallario

DOE Division of Occupational and Environmental Safety

Washington, D.C. 20545

R. V. Griffith

Lawrence Livermore

National Laboratory

Livermore, CA 94550

2 P. Plato/J. Miklos University of Michigan

Ann Arbor, MI 48109

ONSITE

50 Pacific Northwest Laboratory

J. L. Baer

G. W. R. Endres

T. H. Essig

L. G. Faust

W. A. Glass

G. R. Hoenes

J. C. McDonald (25)

P. L. Roberson

J. M. Selby

C. M. Unruh

Technical Information (5)

Publishing Coordination (2) 



\begin{tabular}{|c|c|}
\hline $\begin{array}{l}\text { U.S. NUCLEAR REGULATORY COMMISSION } \\
\text { BIBLIOGRAPHIC DATA SHEET }\end{array}$ & $\begin{array}{l}\text { 1. REPORT NUMBER (Assigned by DDC) } \\
\text { NUREG/CR-2957 } \\
\text { PNL-4590 }\end{array}$ \\
\hline $\begin{array}{l}\text { 4. TITLE AND SUBTITLE (Add Volume No., if epropriser) } \\
\text { Measurement of Ganma-ray Dose from a Moderated }{ }^{252} \mathrm{Cf} \\
\text { Source }\end{array}$ & \begin{tabular}{|l} 
3. RECIPIENT'S ACCESSION NO. \\
\end{tabular} \\
\hline $\begin{array}{l}\text { 7. AUTHOR(S) J, C. McDonald, Pacific Northwest Laboratory } \\
\text { R. V. Griffith, Lawrence Livermore National Laboratory } \\
\text { P. Piato and J. Miklos, University of Michigan }\end{array}$ & \begin{tabular}{|l|r} 
5. DATE REPORT COMPLETED \\
MONTH & YEAR \\
February & 1983 \\
\end{tabular} \\
\hline \multirow[t]{3}{*}{$\begin{array}{l}\text { 9. PERFORMING ORGANIZATION NAME AND MAILING ADDRESS (Include Zip Code) } \\
\text { Pacific Northwest Laboratory } \\
\text { Richland, WA } 99352\end{array}$} & \begin{tabular}{|l|l|}
\multicolumn{2}{|l|}{ DATE REPORT ISSUED } \\
$\begin{array}{l}\text { MONTH } \\
\text { June }\end{array}$ & YEO\&3 \\
\end{tabular} \\
\hline & 6. (Leave blank) \\
\hline & 8. (Leave brank) \\
\hline \multirow{2}{*}{$\begin{array}{l}\text { 12. SPONSORING ORGANIZATION NAME ANO MAILING ADDRESS (Include Zip Code) } \\
\text { Division of Facility Operations } \\
\text { Office of Nuclear Regulatory Research } \\
\text { U.S. Nuclear Regulatory Commission } \\
\text { Washington, DC } 20555\end{array}$} & 10. PROJECT/TASK/WORK UNIT NO. \\
\hline & $\begin{array}{l}\text { 11. CONTRACT NO. } \\
\text { B2460-2 }\end{array}$ \\
\hline $\begin{array}{l}\text { 13. TYPE OF REPORT } \\
\text { Research }\end{array}$ & dates) \\
\hline
\end{tabular}

15. SUPPLEMENTARY NOTES

14. (Leave bank)

16. ABSTRACT (200 words or less)

The gamma-ray dose fraction from a moderated ${ }^{252} \mathrm{Cf}$ source was determined by using three types of dosimetry systems. Measurements were carried out in air at a distance of $35 \mathrm{~cm}$ from the surface of the moderating sphere $(50 \mathrm{~cm}$ from the source which is at the center of the sphere) to the geometrical center of each detector. The moderating sphere is a $0.8 \mathrm{~mm}$ thick stainless steèl shell filled with $\mathrm{D}_{2} 0$ and covered with $0.5 \mathrm{~mm}$ of cadmium. Measurements were also carried out with instruments and dosimeters positioned at the surface of a $40 \mathrm{~cm} \times 40 \mathrm{~cm} \times 15 \mathrm{~cm}$ plexiglass frradiation phantom whose point surface was also $35 \mathrm{~cm}$ from the surface of the moderating sphere. A-150 tissue-equivalent (TE) plastic ionization chambers and a TE proportional counter (TEPC) were used to measure tissue kerma, from which the neutron dose equivalent was computed. The ratio of gamma-ray dose to the neutron dose equivalent was determined by using a relatively neutron insensitive Geiger-Mueller (GM) counter and thermoluminescent dosimeters (TLD). In addition, the event-size spectrum measured by the TEPC was also used to compute the gammaray dose factors. The average value for the ratio of gamma-ray dose to neutron dose equivalent was found to be 0.18 with an uncertainty of $\pm 18 \%$.

17. KEY WORDS AND DOCUMENT ANALYSIS

17a. DESCRIPTORS

Gamma-ray, ggse fraction,

moderated, ${ }^{252} \mathrm{Cf}$ source,

neutrons

17b. IDENTIFIERS/OPEN-ENDED TERMS 
